\title{
Influence of Investment Decisions on the Financial Performance of SACCOS: A Survey of Registered SACCOS in Baringo County
}

\author{
Rotich David Kipkorir ${ }^{1}$, Barbara M. Namiinda ${ }^{2}$, Doreen Njeje $^{3}$ \\ Kenya Methodist University, Department of Business Administration, P. O. Box 3654-20100 Nakuru \\ ${ }^{2}$ Kenya Methodist University, Nakuru Campus, P. O. Box 3654-20100 Nakuru \\ ${ }^{3}$ Kenya Methodist University, Nakuru Campus, P. O. Box 3654-20100 Nakuru
}

\begin{abstract}
The purpose of this study was to assess the influence of investment decisions on the financial performance of registered SACCOs in Baringo County. The objectives of the study were to determine the influence of investment in real estate, FOSA activities, lending to members and lending to government on the financial performance of registered SACCOs. The study was guided by the stakeholder theory, information theory and decision making theory. The study was based on a descriptive survey design and targeted 316 members in 73 registered SACCOs in Baringo County. Stratified sampling was used in selecting a sample size of 177 respondents. Data was collected using questionnaires and analyzed using both descriptive (means and standard deviation) and inferential statistics (regression analysis). The study concludes that investment in real estate influenced $9.8 \%$ of the financial performance of SACCOs in Baringo County while $15.3 \%$ of registered SACCOs' financial performance was explained by lending to members. The study also concludes that FOSA activities influenced $16.6 \%$ of registered SACCOs' financial performance in Baringo County while $10.7 \%$ of SACCOs' financial performance was explained by lending to the government. The highest influence was explained by FOSA activit ies, followed by lending to members, then lending to the government and finally investment in real estate.
\end{abstract}

Keywords: Influence, Financial Performance, Investment Decisions, Registered SACCOs, , investment in real estate, FOSA activities, lending to SACCO members, government bills and bonds

\section{Introduction}

Investment is defined as the process of mobilizing of resources to undertake a given activity with expectation of future returns (Donald, 2010). Literally the word investment means the action of putting something somewhere else in order to get a return. It involves the purchase of an asset or equivalently a deposit to a bank with the hope of getting a future return or interest from it (Prasanna, 2008). Investment decision making is an important part of the strategic decision-making in every enterprise because investment projects essentially affect future economic results and dramatically contributes to the growth of an enterprise. The quality of investment decision is affected by a large number of factors, while the most important is the selection of investment projects (Hana, 2010).

According to Mantrala and Naik (2007) when deciding on an investment option, managers need to know whether they are in the uphill side or on the downhill side of the profit function with respect to each investment variable. The lack of knowledge about the firm's location, leads managers to make serious errors in their investment decision (Thorson, 2007). Seibel and Parhusip (1998) have observed that internal resource mobilization and sound utilization of funds are the grounds for sustainable investment decision. Hagerman and Kenkel (2000) in their research on evaluating investment opportunities in Canada reccommended that in looking at investment opportunities, firms should use payback period, internal rate of return, net present value, profitability index, discounted payback, risk involved, potential to increase customer base, market share and the potential of the service to increase service to members.
According to Dlamini (2011) SACCOs are associations of people who pool together their financial and human resources for the purpose of providing loans for each member and using the pool of ideas for the betterment of the lives of the members. SACCOs are formed to mobilize savings from which they can make loans at reasonable rates of interest (Phikwe, 2004). All over the world SACCOs remain the most important players in the provision of financial services than any other type of financial institution (Thiagarajan, 2011). They provide savings, credit and insurance services to a large portion of the population. In Kenya, the cooperative movement dates back to 1931 when the first ordinance to regularize the operations of the cooperatives was enacted. Currently SACCOs are registered and regulated under the Co-operative Societies Act. However, SACCOs are restricted in terms of where to invest their funds or deposits (Sacco Act, 2008).

The importance of SACCOs' stability is noteworthy as any distress may affect the development plans thereby lowering the economic progress (Thiagarajan, 2011). The stability of SACCOs is therefore a pre-requisite for economic development and resilience against financial crisis (Chambo, Mwangi \& Oloo, 2013). Like any other business, success of SACCOs is assessed based on profit and quality of asset it possesses. Even though SACCOs serve social objectives through its priority sector lending and membership, maintaining asset quality and profitability is critical for SACCOs' survival and growth. In comparison with other East African economies, Kenya's financial sector has for many years been credited for its size and diversification (Kithinji, 2010: Gaitho, 2013). SACCOs are able to advance 


\section{International Journal of Science and Research (IJSR) \\ ISSN (Online): 2319-7064 \\ Index Copernicus Value (2013): 6.14 | Impact Factor (2015): 6.391}

loans at interest rates lower than those charged by other financial providers. In addition, SACCOs have the ability to reach clients in areas that are unattractive to banks, such as rural or poor areas. This has made SACCOs more attractive to customers, thus deeply entrenching themselves in the financial sectors of many countries (Munyiri, 2006).

In Kenya, SACCOs have mobilized over Kshs.200 billion in savings, accounting for over $30 \%$ to National Domestic Saving (ROK, 2010). Savings mobilization should be backed by adequate institutional capital which ensures permanency, provide cushion to absorb losses and impairment of members' savings (Evans, 2001). The institutional capital, which comprises the core capital and less share capital, is mainly accumulated from appropriation of the surpluses. Therefore, SACCOs should strive to maximize on the earnings by build their institutional capacities (Ombado, 2010).

Financial performance is the results of a firm's policies and operations in monetary terms. It is the results of many different activities undertaken by an organization (Thiagarajan, 2011). There are varied measures of financial performance. In traditional management studies, ratios are used and are classified according to the following performance aspects measured: profitability, liquidity, leverage, and efficiency (Mwaura, 2005). These ratios can be computed directly using financial statement information. Valuation ratios are added with the traditional classification of ratios, which incorporate more current assessments by the market of the company's net worth. Simple balance sheet and income statement items are used to compute ratios to analyze financial statements of the financial institutions. The essence of financial performance measurement is to provide the organization with the maximum return on the capital employed in the business (Ngui, 2010).

In Kenya, SACCOs account for three quarters (75\%) of the financial subsector's assets, deposits and membership. Due to the nature of their business, SACCOs are regulated prudentially under the Sacco Societies Regulations Act (SASRA). The Act provides for licensing and supervision of SACCOs in a manner befitting other deposit taking financial institutions. During the year 2012/2013, the Authority licensed eleven SACCOs and renewed licenses for one hundred and twenty-four Registered SACCOs. This brought the total licensed SACCOs to one hundred and thirty-five (135) out of the two hundred and fifteen (215) applications received from 2010 when the prudential regulatory framework came into force. The remaining eighty SACCOs had up to June 2016 to satisfy the licensing requirements or cease deposit taking business (Lewis, 2004).

In Baringo County there are 73 registered SACCOs. Although investment decision made by these SACCOs has significantly revolutionized lending and contributed to reduced financial performance of many SACCOs, the SACCOs are facing an enormous investment risk exposure. The investment activities SACCOs in Baringo County are engaged in include housing, farming and general business. There many SACCOs provide exposure to a wide range of investment opportunities in various equities and related assets classes. However, coupled with the fear of losing members, the SACCOs have not completely embraced divergent investment decision in the area. In this respect some SACCOs in the area have continued to experience loan loss, reduced profitability and members' withdrawal of savings. Consequently studies were required to establish the extent to which investment decision may maximize financial performance of SACCOs in the area.

\subsection{Statement of the Problem}

The investment decision in SACCOs is considered as one of the principles of concern for the shareholders. This is because investment decisions determine the SACCOs financial performance. Analysis of investment decisions made by SACCOs in Baringo County shows that there have been challenges that have lowered their financial performance. Low return on real estate investment, irregular membership fee remittances, inadequate product development, delay in loan processing, increased levies on withdrawal and deposit and loan default are some of the key challenges that have affected the financial performance of SACCOs in Baringo County (Sigei, 2013). This has resulted into decreased profits and membership withdrawal of savings. Hence some SACCOs have been unable to mobilize savings for additional investment. However, studies on the influence of investment decisions on financial performance of SACCOs in Baringo County are rather scanty. Mwangi and Kihiu (2012) established that the probability of a firm depends on the investment decision adopted by the firm. Muriuki (2016) analyzed factors influencing investment decisions of SACCOs' in Kenya and found that the level of financial literacy of the fund managers influenced their investment decision making. These studies concentrated on areas of financial literacy but not on investment decision in SACCOs. Therefore, the influence of investment decisions on financial performance of SACCOs in Baringo County has not been established. Therefore, it was imperative to assess the influence of real estate investment, FOSA activities, lending to members and lending to government on financial performance of SACCOs in Baringo County.

\subsection{Research Objectives}

1) To determine the influence of investment in real estate on financial performance of SACCOs in Baringo County.

2) To establish the influence of FOSA activities on financial performance of SACCOs in Baringo County.

3) To establish the influence of lending to SACCO members on the financial performance of SACCOs in Baringo County.

4) To establish the influence of investment in government bills and bonds on the financial performance of SACCOs in Baringo County.

\section{Literature Review}

\subsection{Theoretical Review}

The theories that guided this study are discussed in this section. The study was guided by four theories namely decision making theory, the stakeholder theory and the agency theory.

\section{Volume 5 Issue 4, April 2016




\section{International Journal of Science and Research (IJSR) \\ ISSN (Online): 2319-7064 \\ Index Copernicus Value (2013): 6.14 | Impact Factor (2015): 6.391}

\subsubsection{Decision Making Theory}

The decision theory was pioneered by Herber Simon in 1952 (Freeman, 2008). The theory is concerned with the identification of the best decisions to take. Thus, the use of mathematical approaches in financial analysis like ratios to analyze and explain the relationship among variables, identification of current assets to current liabilities and the decision on what to buy is the primary goals of this theory. With the decision making theory investment cannot be viewed as a discipline with practically interaction with other operating functions of the business (Freeman, 2008). One of important assumptions in decision making process is existence of quality information. Significant number of this information comes from accounting information systems and from financial statements. Financial statements have to provide realistic and objective picture of realistic business conditions of certain companies. In the context of consideration of financial statements as a function of decision making, financial statements provide whole number of different instruments, analyses and procedures for understanding business. A well established process of management on the basis of financial statements and financial information is one of the most significant presumptions of the quality of business. In the context of SACCOs, the functions are intertwined with managerial analysis because, as an information system it provides significant and meaningful financial information about the SACCOs both for internal management use and external financial applications (Freeman, 2008).

\subsubsection{Stakeholder Theory}

This theory holds that the interest of the stockholders need not harm stakeholders (Freeman, 2008). It also holds that an organization can enhance the interests of its stakeholders without damaging the interest of its wider stockholders. This theory grew in response to the economic theory of the firm. Applied to SACCOs, the SACCOs' investment decision maker has a responsibility to provide the stakeholders with the reports on the operations of the SACCOs' risk management, control and financial management processes as well as the SACCOs' spending plans (Haber, 2004). This theory was considered relevant in guiding this study because it makes prediction about the role of investment decision in making financial reports (Lavio, 2002).

\subsubsection{Agency Theory}

Agency problem simply refers to the principal-agent problem where the principal is the holder of the stocks and the agent is the manager. Investment decisions can be seen as a tool to reduce agency costs. The main duties of the manager would be to manage the firm effectively and efficiently so as to maximise the firm's value and also maximise returns to the shareholders. However, agency problem arises when managers' and shareholders' interests are not in line with each other. This may arise since the manager is not acting in the interest of the shareholders, for example, the manager is not investing in projects that the shareholders consider to be worth investing. Hence the cost of monitoring the managers is referred to as the agency costs. However, another problem that exists in this case is that the managers are involve in the daily running of the business and they are more aware about which investment should bring higher positive returns. However, it has been observed that if managers are not monitored properly, they tend to surround themselves with luxury products and also tend to pursue their personal interests which in most cases would be to maximise their wages instead of returns to shareholder (Jensen \& Ruback, 2005). Hence one method which can be argued to help overcome the agency problem is through investment decision payouts. Funds raised are mostly through loans from banks, insurance companies and other credit institutions. These institutions will be acting as a control since, by giving credit, they would be able to monitor the activities of the company to determine whether the company is being able to repay its debt obligations. Since SACCOs also monitor the firm, shareholders accept to pay higher tax rates as they do not incur or incur less cost in monitoring the activities of the managers to ensure that firm value is being maximized. On the other hand, with such monitoring, the firm will have to produce positive cash flows thereby generating profits. Hence, investment decision payouts not only reduce the agency problem but also convey some information about future earnings.

\subsection{Empirical Review}

This section reviews previous studies related to the study topic. It presents analyses of literature on investment decisions and their effect on financial performance of SACCOs.

\subsubsection{Investment in Real Estate}

According Elhiraika (2011) real estate investment decision is one of the fundamental decisions of business management. The assets may be physical such as real estates or machinery, intangible, or financial. Some SACCOs engage in asset investment particularly in real estate. The continued viability of financial investments depends on its ability to earn an appropriate return on its assets which enables it to fund expansion, remain competitive and replenish capital. The growth of SACCOs' wealth is represented by the value of its net assets and an increase in these assets translates to effective investment on assets. The funds invested by the members of the SACCOs can generate enough surpluses to contribute to institutional capital as they provide for investment decisions. The institutional capital consists of the capital reserves and accumulated surpluses which SACCOs have generated through retained surpluses. The institutional capital, which is a plough back of the income from investments, reflects the surpluses of SACCOs.

Wasike (2012) conducted a study on the influence of corporate governance practices on performance of Elimu SACCOs in Kenya and found out that corporate governance ensured corporate efficiency and mitigated arising conflicts, provided transparency and legitimacy of corporate activity, lowered risk for investments and provided high returns for investors. Ngaira (2011) studied the impact of SACCO regulatory authority guidelines on SACCO operations in Nairobi County and established that SASRA regulations greatly impacted on the financial performance of SACCOs in terms of outreach and sustainability which were attributed to increased membership, high efficiency, high demand and quick recoveries. Mbui (2010) conducted a study on the business opportunities for Stima SACCO in a new regulatory environment and found out that the new 


\section{International Journal of Science and Research (IJSR) \\ ISSN (Online): 2319-7064 \\ Index Copernicus Value (2013): 6.14 | Impact Factor (2015): 6.391}

regulatory environment provided more structured and clear guidelines on the operations of Stima SACCO, thus creating more customer confidence and more dynamic and enabling environment for business growth.

\subsubsection{Lending to Members of SACCOs}

One of the investment decisions is to lend to members of the SACCOs. However, with the growth of the number of SACCOs in Kenya, access to credit is not difficult but repayment is never $100 \%$ (Besley \& Coate, 2005). SACCOs use the deposits of their members to advance money to borrowers. The lender is expected to recoup the financial capital after the agreed period of time otherwise the borrowers will benefit at the expense of lenders. If loan repayment fails and this continues, then bankrupt will be ultimate result. In Africa loan, repayment performance has been poor. A study by Ochoki (2007) found that there was lack of planning and inadequate capital in SACCOs which affected growth. Accordingly, SACCOs should ensure sound business practices and consider safety and liquidity. In a study by Muruana (2007) found that failing loan portfolio, erosion in value of members' shares and loss of value affected SACCOs' wealth. A study by Hein (2008) found that increasing shareholder power would either have positive, negative or intermediate effects on capacity utilization, profits and capital accumulation. Papias and Ganesa (2009) study found out that age, gender and size of the household, purpose for credit, interest rate charges and number of official visits to the credit societies, had a strong effect on loan repayment performance whereas size of credit disbursed, credit processing and disbursing time, borrowers' market place and income transfer from relatives. The remaining factors have logical and explainable signs but are not statistically significant.

\subsubsection{FOSA Activities of SACCOs}

Some SACCOs charge different interests on FOSA activities. These constitute investments for these SACCOs. Interest rates differ mainly in terms of maturity. When maturity and liquidity together with other factors are considered, many different financial instruments and so many different interest rates will emerge (Anyanwu, 2005). Interest rates can either be nominal or real. A lot has been reviewed in terms of lending activities of SACCOs. Papias and Ganesa (2009) examined the factors contributing to credit repayment behaviour among the members of FOSAs in rural Rwanda but failed to address the factors that determined growth in wealth. According to Mbaabu (2004) delays in approval, project under financing and lending not based on security affect the growth of wealth. The government should encourage sound governance policies that keep the financial standards at the core of internal management and external supervision and support competent and independent external supervision of SACCOs. The government should also increase level of commitment, harmonize existing legal statutes, intensify follow-up. Olando, Mbewa and Jagongo (2012) studied the financial practice as a determinant of growth of SACCOs with a view to ameliorating the socio-economic development of SACCCOs in Meru County and established that the financial performance of SACCOs depended on financial stewardship, capital structure and funds allocation strategy. The study further found that SACCOs inadequately complied with their by-laws but incomes from investments did not adequately cover their costs.

\subsubsection{Lending to Government}

Lending to the government by buying treasury bonds has been considered as one of the innovative investment decisions by SACCOs. Investment in treasury bills is a risk free investment option in Kenya. Investing in treasury bills is actually a loan you give to the Kenya government through the Central Bank. The government promises to pay you back with interest after a certain period. To invest in treasury bills in Kenya, one must open a CDS Account with Central Bank of Kenya. Just like treasury bills, treasury bonds are also issued by the government to raise money. The difference is that treasury bills are longer term instruments over 1 year and the minimum investment amount is Sh. 50,000. Investment in treasury bonds is therefore a good investment idea in Kenya for those who are busy and want to earn some passive income without breaking a sweat. The most important thing is to do research and make wise decisions, understand thoroughly how the investment works and diversify the investment.

According to Koen (2007) this can bring incremental revenues to SACCOs as it is considered to be cost effective, and an improvement to existing products line addition to existing platforms and repositioning of existing products introduced into the market while breakthrough products are new to the company and also new to the world have greater performance and highly improved, platform products establish a basic architecture for next generation product. Systematic inventive thinking is a highly disciplined approach to new product idea generation that represents both the interest of customer and the company. According to Armstrong (2006) the elements of a product in terms of physical components and attributes are important means of improving the performance of an organization. Motinho and Geoff (2006) cite the importance of lending to the government based on the fact that there is transparency in terms of fixed returns. This is because the bonds often mature with a fixed period of time with a fixed rat of return.

Muriuki (2010) studied the factors affecting SACCOs' financial performance in Meru County. The broad objective of the study was to investigate the effects management variables on SACCO's financial performance in the TNT SACCO. Descriptive research design was used in this study. Since the population was not homogeneous, stratified random sampling design was used to draw the study sample. The results show that governance, education and training play a major role on influencing investment decision in SACCOs. Wasike (2012) conducted a study on the use of corporate governance as a post liberalization strategy by SACCOs in Bungoma County and reported that despite adopting governance strategies, many SACCOs were yet to reap maximum returns. Ndubi (2006) conducted a study on strategic responses of SACCOs to changing operating environment in Nyandarua County and found out that SACCOs have made various changes in their traditional resource mobilization and investment strategies in an attempt to cope with the changed operating environment.

\section{Volume 5 Issue 4, April 2016}




\section{International Journal of Science and Research (IJSR) \\ ISSN (Online): 2319-7064 \\ Index Copernicus Value (2013): 6.14 | Impact Factor (2015): 6.391}

\subsubsection{Financial Performance}

Financial performance is the results of a firm's policies and operations in monetary terms. Common examples of financial performance include operating income, earnings before interest and taxes, and net asset value (Cole, 2004). There are two major reasons as to why organizations should have financial performance measurement. The first one is to produce financial statements at the right time. According to Mwaura (2016) financial performance can be measured in terms of profitability, liquidity, leverage, and efficiency. The financial performance of a SACCO is measured through the ability of the institution to meet the financial demands of its members taking consideration of economic status of the members. SACCOs are expected to give better and cheaper services to its members as compared to the main stream banks because SACCO understands the needs of the members because they are the owners of the SACCO.

\subsection{Conceptual Framework}

The conceptual frame work below illustrates the interaction between the independent variables and intervening variable which influence the dependent variable.

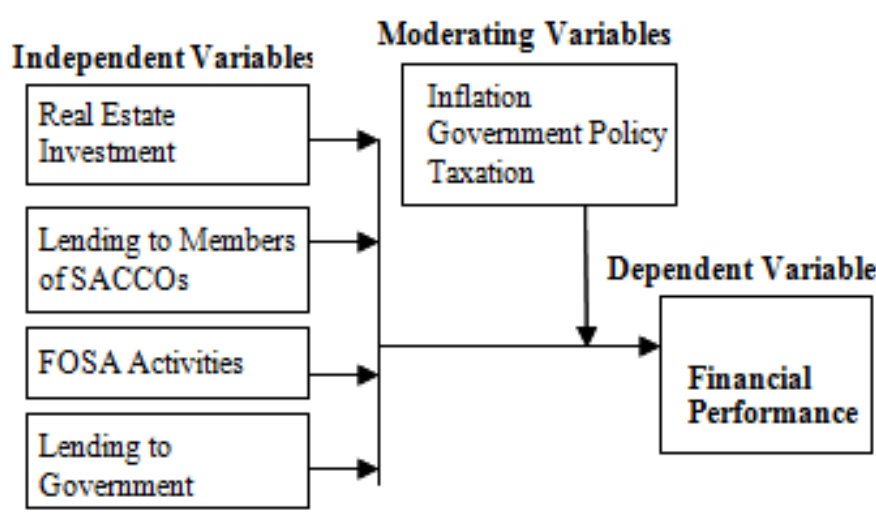

Figure 1: Conceptual Framework

Source: Own Conceptualization (2016)

The conceptual framework shows that investment in real estate, FOSA activities, lending to members and lending to government form the independent variables which affect the financial performance of SACCOs. If investment decisions are efficient they may lead to sound financial performance of SACCOs. However, the interaction between these variables was moderated by inflation, government policy and taxation.

\section{Methodology}

\subsection{Research Design}

The study adopted a descriptive survey research design. The descriptive design allowed simultaneous description of views, perceptions and beliefs of the respondents at a given point in time. The design was also considered appropriate for obtaining factual and attitudinal information about the opinions of the respondents on the study variables.

\subsection{Target Population}

The population of the study involved the staff of SACCOs in Baringo County. There were 73 registered SACCOs in Baringo County with a total of 316 members ranging from administrators, credit officers, internal auditors and information technology officers all of whom were involved in the study. The target population was considered appropriate because they had adequate knowledge on investment decisions.

\subsection{Sampling Technique and Sample Size}

The sampling plan describes the procedures used in determining the sample size. In this study, the sample size was drawn from the members in SACCOs in Baringo County. Stratified random sampling was employed in the selection of the sample size. This involves a process of stratification (different strata are made on the basis of different management levels) and a random sample is then drawn from each stratum (Sekaran \& Bougie, 2010). From each category (stratum), an equal number of respondents were selected to constitute the sample size. To obtain a representative sample size Yamane's formula (1973) for the determination of the sample size was used: $\mathbf{n}=\mathrm{N} /\left(1+\mathrm{Ne}^{2}\right)$, Where: n: sample size, N: Target Population, e: Standard error with 0.05 as the level of significance. The sample size obtained from this formula was 177 respondents.

\subsection{Data Collection}

Secondary data was collected from journals, empirical studies and reported statements of accounts of the targeted SACCOs. The study obtained primary data by the use structured questionnaires. The questionnaire was used because it is a valuable tool for collecting a wide range of data from a large number of respondents. It is also straightforward and easy to analyze. The questionnaires were mainly closed ended for ease of analysis.

\subsection{Data Analysis and Presentation}

The returned instruments were scrutinized to determine correctness and accuracy of the responses. The data collected was coded based on the variables that were studied. Cross tabulations were generated to explain the various attributes of the variables studied and to represent the quantitative data. The data was analyzed using both descriptive and inferential statistics with the aid of SPSS. Descriptive statistics involved the use of percentages, frequency, means and standard deviations. Tables were also used to represent the data collected for ease of analysis. Linear regression analysis was applied to determine the relative influence of investment decisions on financial performance in SACCOs. The regression model was as follows: $\mathbf{Y}=\alpha+\boldsymbol{\beta}_{1} \mathbf{x}_{1}+\boldsymbol{\beta}_{2} \mathbf{x}_{2}+\boldsymbol{\beta}_{3} \mathbf{x}_{3}+\boldsymbol{\beta}_{4} \mathbf{x}_{4}+\varepsilon$

Where: $\mathrm{Y}=$ Financial Performance

$\alpha=$ Constant Term

$\beta_{1}$ to $\beta_{4}$ = Regression Coefficients

$\mathrm{x}_{1}=$ Investment in Real Estate

$\mathrm{x}_{2}=$ FOSA Activities

$\mathrm{x}_{3}=$ Lending to Members

$\mathrm{x}_{4}=$ Lending to Government

$\mathrm{e}=$ Error 


\section{International Journal of Science and Research (IJSR) ISSN (Online): 2319-7064 \\ Index Copernicus Value (2013): 6.14 | Impact Factor (2015): 6.391}

\section{Results}

\subsection{Investment in Real Estate of SACCOs in Baringo County}

This section presents the descriptive analysis of results of the study on investment in real estate by SACCOs in Baringo County. The results were analyzed using mean and standard deviations of the responses. The results are presented in Table 1.

Table 1: Descriptive Statistics on Investment in Real Estate by SACCOs

\begin{tabular}{|c|c|c|c|c|c|}
\hline Indicators & $N$ & Min & Max & Mean & SD \\
\hline $\begin{array}{c}\text { Our SACCO selects the correct type } \\
\text { of real estate investment }\end{array}$ & $\mathbf{1 4 2}$ & $\mathbf{1}$ & $\mathbf{5}$ & $\mathbf{3 . 4 2}$ & $\mathbf{1 . 0 1}$ \\
\hline $\begin{array}{c}\text { In our SACCO there is sufficient } \\
\text { information about the type of } \\
\text { investment available }\end{array}$ & $\mathbf{1 4 2}$ & $\mathbf{1}$ & $\mathbf{5}$ & $\mathbf{3 . 0 8}$ & $\mathbf{0 . 9 6}$ \\
\hline $\begin{array}{c}\text { Shareholders are aware of members' } \\
\text { level of satisfaction with the type of } \\
\text { investments chosen by the SACCO }\end{array}$ & $\mathbf{1 4 2}$ & $\mathbf{1}$ & $\mathbf{5}$ & $\mathbf{3 . 4 7}$ & $\mathbf{0 . 8 3}$ \\
\hline $\begin{array}{c}\text { The SACCO offers a good rate of } \\
\text { return on savings to members }\end{array}$ & $\mathbf{1 4 2}$ & $\mathbf{1}$ & $\mathbf{5}$ & $\mathbf{3 . 2 1}$ & $\mathbf{0 . 3 9}$ \\
\hline $\begin{array}{c}\text { The degree of risks associated with } \\
\text { Investment policies in our SACCOs } \\
\text { is high. }\end{array}$ & $\mathbf{1 4 2}$ & $\mathbf{1}$ & $\mathbf{5}$ & $\mathbf{3 . 3 4}$ & $\mathbf{0 . 5 3}$ \\
\hline $\begin{array}{c}\text { Real estate investment has increased } \\
\text { the SACCOs profitability }\end{array}$ & $\mathbf{1 4 2}$ & $\mathbf{1}$ & $\mathbf{5}$ & $\mathbf{3 . 3 5}$ & $\mathbf{0 . 6 6}$ \\
\hline $\begin{array}{c}\text { The SACCO invests members fund } \\
\text { prudently }\end{array}$ & $\mathbf{1 4 2}$ & $\mathbf{1}$ & $\mathbf{5}$ & $\mathbf{2 . 9 7}$ & $\mathbf{0 . 9 8}$ \\
\hline $\begin{array}{c}\text { Real estate investment decisions } \\
\text { affect overall SACCO performance }\end{array}$ & $\mathbf{1 4 2}$ & $\mathbf{1}$ & $\mathbf{5}$ & $\mathbf{3 . 2 4}$ & $\mathbf{0 . 5 7}$ \\
\hline
\end{tabular}

Source: Author (2016)

The results as reflected in table 1 suggest that respondents agreed that their SACCO selected the correct type of real estate investment as reflected by a mean response of 3.42 . However, a significant standard deviation of 1.01indicated that there were variations in responses concerning whether the SACCOs selected the correct type of real estate investment. Results regarding whether in the SACCOs there was sufficient information about the type of investment available, the results shows that the respondents were indifferent as revealed by a mean value of 3.08. However, the standard deviation of 0.14 revealed varied responses in regard to this indicator. It is also revealed that the respondents agreed that sshareholders were aware of members' level of satisfaction with the type of investments chosen by the SACCOs as revealed by a mean value of 3.47. However, the corresponding standard deviation of 0.89 reveals that there was relatively high variation in responses from the respondents.

Concerning whether the SACCOs offered a good rate of return on savings to members, the results show slight agreement as reflected by a mean value of 3.21 while the corresponding standard deviation of 0.39 shows that there were also slight variations in the responses as far as this indicator was concerned. The respondents also slightly agreed that the degree of risks associated with Investment policies in their SACCOs was high as shown by a mean value of 3.34. Nevertheless, a standard deviation of 0.53 suggested slight variation in the responses as far as this indicator was concerned.

In regard to whether investment in real estate had increased the SACCOs profitability, the respondents slightly agreed as revealed by a mean of 3.35 with a standard deviation of 0.66 which also suggested slight variation in responses as far as this test was concerned. The findings also show that the respondents slightly disagreed that their SACCO invested members fund prudently as revealed by a mean value of 2.97 although the standard deviation of 0.98 indicates the respondents varied greatly as far as this test was concerned. Finally it is evident that slightly more than half of the respondents agreed that real estate investment decisions affected the overall SACCOs' financial performance as shown by a mean response rat of 3.24 with a standard deviation of 0.57 . These findings concur with a previous study by Ombado (2010) which indicating that SACCOs are diversifying their investment portfolios in order to improve their financial performance. This implies that policy changes are required to create a favourable investment environment for SACCOs.

\subsection{Lending to Members of SACCOs}

The second objective of the study sought to examine the influence of lending to members on financial performance of SACCOs in Baringo County. The indicators of lending to members by SACCOs were analyzed in terms of their mean and standard deviation and the findings presented in Table 2.

Table 2: Indicators of Lending to Members in SACCOs

\begin{tabular}{|c|c|c|c|c|c|}
\hline SACCOs' Lending to Members & $\mathbf{N}$ & Min & Max & Mean & SD \\
\hline SACCOs have non performing loans & 142 & 1 & 5 & 4.00 & 0.60 \\
\hline $\begin{array}{c}\text { SACCOs receive members' } \\
\text { contribution regularly }\end{array}$ & 142 & 1 & 5 & 2.55 & 0.92 \\
\hline $\begin{array}{c}\text { SACCOs do not lend to members } \\
\text { who default in paying their loans }\end{array}$ & 142 & 1 & 5 & 2.79 & 1.06 \\
\hline $\begin{array}{c}\text { SACCOs prevents loan defaulters } \\
\text { from accessing credits from other } \\
\text { SACCOs }\end{array}$ & 142 & 1 & 5 & 3.13 & 0.84 \\
\hline $\begin{array}{c}\text { Our SACCO incurs a lot of costs in } \\
\text { recovering loans given to customers }\end{array}$ & 142 & 1 & 5 & 2.92 & 1.05 \\
\hline $\begin{array}{c}\text { In cases of failure to pay loan the } \\
\text { SACCOs' management takes } \\
\text { measures to recover it }\end{array}$ & 142 & 1 & 5 & 3.81 & 0.89 \\
\hline $\begin{array}{c}\text { The number of members applying } \\
\text { for loans SACCO has change over } \\
\text { the last 2 years }\end{array}$ & 142 & 1 & 5 & 3.34 & 1.07 \\
\hline $\begin{array}{c}\text { The members' shares sustain the } \\
\text { SACCO operation without } \\
\text { outsourcing credits }\end{array}$ & 142 & 1 & 5 & 2.95 & 0.72 \\
\hline
\end{tabular}

Source: Author (2016)

As shown in Table 2 majority of the respondents were in agreement that SACCOs had non performing loans as reflected by a mean value of 4.0. However, the standard deviation of 0.6 suggested slight variation in responses in regard to the same test. Moreover, the findings pertaining to whether SACCOs received members' contribution regularly shows a mean response rate of 2.55 which is below the average. This suggests that majority of the respondents disagreed that their SACCOs received members' contribution regularly. However, a standard deviation of 


\section{International Journal of Science and Research (IJSR) \\ ISSN (Online): 2319-7064 \\ Index Copernicus Value (2013): 6.14 | Impact Factor (2015): 6.391}

0.92 suggested a relatively high variation in their responses. This could be due to what Phikwe (2004) describes as lack of a clear understanding of the internal control systems to monitor members' contribution.

It is also evident that the respondents seemed to disagree as to whether SACCOs lent to members who defaulted in paying their loans. This is revealed by a mean of 2.79 . However, a standard deviation of 1.06 suggests a significant variation in their responses. This means that the importance of lending to members of SACCOs as required has not been achieved in Baringo County. Moreover, the findings suggest that the respondents slightly agreed that SACCOs prevented loan defaulters from accessing credits from other SACCOs. This is revealed by a mean response rate of 3.13. However, the standard deviation of 0.84 suggests slightly lower variation in the responses. Higher response rate in regard to this indicator concurs with Phikwe, 2004's suggestion that SACCOs should develop elaborate mechanisms to prevent loan defaulters from accessing credits from other SACCOs and to reinforce ethical behaviour among the members. The findings in regard to whether SACCOs incurred a lot of costs in recovering loans given to customers revealed a mean value of 2.92 which is slightly below the average. However, a significant standard deviation of 1.05 which suggests that in as much as the respondents tend to disagree that their SACCOs incurred a lot of costs in recovering loans given to customers, they varied greatly in their responses. This could also imply that the respondents might not be aware of the cost implication of debt recovery.

Also, it can be deduced that respondents agreed that in cases of failure to pay loan the SACCOs' management took measures to recover it. This is revealed by a mean value of 3.81, although the standard deviation of 0.89 revealed a relatively higher variation in responses generated. The findings are in agreement with Ombado (2010)'s finding that most loan default often respond positively when they are compelled to make payments.

Also, majority of the respondents marginally agreed that the number of members applying for loans SACCO had changed over the last 2 years as reflected by the mean value of 3.34 . However, a significant standard deviation of 1.07 reveals varied responses from the respondents on the same, implying that they had different opinions on the same indicator. The finding agree with Phikwe (2004) that the objective of SACCOs is to assist members to improve their lives but fear of repaying keep off some members from applying or loans. Moreover, the respondents slightly agreed that the members' shares sustained the SACCOs' operation without outsourcing credits as shown by mean response of 2.95 and a standard deviation of 0.72 . The slight agreement with the statement concurs with Ochoki (2007) who reported that inadequate capital in SACCOs affected their growth.

\subsection{Influence of FOSA Activities on SACCOs' Financial Performance}

This section presents results on the influence of FOSA activities on the financial performance of SACCOs in Baringo County. The findings are based on the extent to which the respondents agreed with different indicators of the
SACCOs' FOSA Activities. The findings have been analysed in terms of means and standard deviations so as to deduce meaning out of the results.

Table 3: Indicators of influence of FOSA Activities on SACCOs

\begin{tabular}{|c|c|c|c|c|c|}
\hline Indicators & $N$ & Min & Max & Mean & SD \\
\hline $\begin{array}{c}\text { FOSA activities give a good rate of } \\
\text { return on savings to members }\end{array}$ & 142 & 1 & 5 & 4.08 & 0.88 \\
\hline $\begin{array}{c}\text { Our SACCO incurs costs in } \\
\text { recovering loans given to } \\
\text { customers }\end{array}$ & 142 & 1 & 5 & 3.71 & 0.98 \\
\hline $\begin{array}{c}\text { Costs of withdrawal and deposits } \\
\text { constitute SACCOs income }\end{array}$ & 142 & 1 & 5 & 4.24 & 0.74 \\
\hline $\begin{array}{c}\text { Ledger fees contributes revenues } \\
\text { for the SACCOs }\end{array}$ & 142 & 1 & 5 & 2.78 & 1.00 \\
\hline $\begin{array}{c}\text { The SACCO charge reasonable } \\
\text { membership fees }\end{array}$ & 142 & 1 & 5 & 3.21 & 0.93 \\
\hline $\begin{array}{c}\text { Investment decisions affect overall } \\
\text { SACCO performance }\end{array}$ & 142 & 1 & 5 & 3.142 & 1.13 \\
\hline $\begin{array}{c}\text { The level of inflation has affected } \\
\text { the interest rate in our SACCO }\end{array}$ & 142 & 1 & 5 & 3.11 & 1.03 \\
\hline $\begin{array}{c}\text { Interest rate charged by our } \\
\text { SACCO affect its growth of } \\
\text { membership }\end{array}$ & 142 & 1 & 5 & 3.01 & 0.81 \\
\hline
\end{tabular}

Source: Author (2016)

As shown in Table 3 majority of the respondents agreed that FOSA activities gave a good rate of return on savings to members as indicated by a mean value of 4.08 . This shows that the respondents generally agreed that FOSA activities offered a good rate of return on savings to members. In addition, the corresponding standard deviation of 0.88 shows that there was no much variation in the responses provided by the respondents about the influence of FOSA Activities on the financial performance of SACCOs in Baringo County.

From Table 3, the respondents agreed that their SACCOs incurred costs in recovering loans given to customers as reflected by the mean value of 3.7. However, a significant standard deviation of 0.98 suggests high variation in responses in regard to whether changes were required to promote the activities of SACCOs. These results rhyme with Speer and Perkins's assertion of the role of loan recovery policies in setting the tone of an organization financial performance. It supports the assertion by Wasike (2012) that financial policies are the foundation for all other components of effective financial performance. Moreover, the results presented in Table 3, in regard to whether ledger fees contributed revenues for the SACCOs shows a mean of 4.24, implying that the respondents agreed with the statement. But a standard deviation of 0.44 suggests no significant difference in responses as regards the whether the ledger fees contributed to revenues for the SACCOs.

The results in respect to whether the SACCOs charged reasonable membership fees showed a mean response of 2.78.This is slightly below the mean average, implying that the respondents slightly disagreed that the SACCOs charged reasonable membership fees. However, a standard deviation of 1.00 reveals that the respondents had varied opinion $n$ this regard. Nevertheless, the findings are in agreement with Odindo (2009) who noted that the financial soundness of a 


\section{International Journal of Science and Research (IJSR) \\ ISSN (Online): 2319-7064 \\ Index Copernicus Value (2013): 6.14 | Impact Factor (2015): 6.391}

SACCO needs to be based on stable cash flow. The results also show that the respondents agreed that the level of inflation had affected the interest rate in their SACCOs as showed by a mean response of 3.9. Nevertheless, the corresponding standard deviation of 0.93 suggests that respondents had significant variations in their responses. However, this could also be construed to imply that respondents might not have clearly understood the interaction between inflation and financial performance of SACCOs. His concurs with findings $\mathrm{n}$ a study done by Adeyemo and Bamire (2005) which pointed out that the government should encourage sound governance policies that keep the financial standards at the core of internal management and external supervision and support competent and independent external supervision of Registered SACCOs. The results further reveal that to some extent the respondents agreed that the interest rate charged by their SACCOs affected the growth of membership as reflected by a mean value slightly above average, 3.11. However, the respondents seemed to have varied in their responses concerning whether interest rate charged by their SACCOs affected the growth of membership as revealed by a standard deviation of 0.83 . The fact that the respondents were not in full agreement suggested that there were no common understanding of the factors affecting the growth of membership in SACCOs in Baringo County.

\subsection{Influence of Lending to Government on Financial performance}

The fourth objective of the study sought to examine the influence of lending to Government on financial performance of SACCOs in Baringo County. Descriptive statistics were used to compute the mean and standard deviations of the results as presented in table 4 .

Table 4: Mean and Standard Deviation of Lending to Government

\begin{tabular}{|c|c|c|c|c|c|}
\hline Statements & $N$ & Min & Max & Mean & $S D$ \\
\hline $\begin{array}{c}\text { Development of new products } \\
\text { involves lending to the government }\end{array}$ & $\mathbf{1 4 2}$ & 1 & 5 & 3.42 & 1.24 \\
\hline $\begin{array}{c}\text { The management relay information } \\
\text { to the members on the intention to } \\
\text { lend to the government }\end{array}$ & $\mathbf{1 4 2}$ & 1 & 5 & 3.32 & 0.74 \\
\hline $\begin{array}{c}\text { Lending to government is based on } \\
\text { the members needs }\end{array}$ & $\mathbf{1 4 2}$ & 1 & 5 & 3.08 & 0.14 \\
\hline $\begin{array}{c}\text { Treasury bonds are chosen due to } \\
\text { high rate of return }\end{array}$ & $\mathbf{1 4 2}$ & 1 & 5 & 3.47 & 0.89 \\
\hline $\begin{array}{c}\text { There is guarantee of return on } \\
\text { investment involving lending to the } \\
\text { government }\end{array}$ & $\mathbf{1 4 2}$ & 1 & 5 & 3.21 & 1.19 \\
\hline $\begin{array}{c}\text { Lending the government is based on } \\
\text { considerations like research and } \\
\text { market survey }\end{array}$ & $\mathbf{1 4 2}$ & 1 & 5 & 3.34 & 0.93 \\
\hline $\begin{array}{c}\text { Our SACCO dos not have capacity } \\
\text { to lend to the government }\end{array}$ & $\mathbf{1 4 2}$ & 1 & 5 & 3.35 & 1.06 \\
\hline
\end{tabular}

Source: Author (2016)

It is evident that the respondents agreed that lending to government was seen as a way of developing new products. This is shown by a mean value of 3.42. However, a significant standard deviation of 1.24 shows that the respondents varied markedly in their responses. This is in line with Elhiraika (2011)'s suggestion that operational governance in the form of clear policies and procedures can reduce incidences of lending to government. According to Donald (2011) decisions to lend to the government should be documented, regularly updated and communicated to members in order to create awareness on the extent to which this has been done. The findings in regard to whether there the management relayed information to the members on the intention to lend to the government suggest that respondents were indifferent as revealed by a mean value of 3.08 . However, a standard deviation of 0.14 reveals minimal variation in the responses as far as this is concerned. This concurs with Elhiraika (2011) who observes that clear policies and procedures are required whenever SACCOs are lending to the government. The results also shows that the respondents tended to agree that lending to the government was based on the members' needs. This is revealed by a mean value of 3.47. The standard deviation of 0.89 reveals that there were varied responses from the respondents. The fact that not lending to the government is based on the members needs is an indication of deficiencies in the investment decision by the management of SACCOs in Baringo County.

Concerning whether treasury bonds were decided upon because of high rate of return, the results reveal a moderate response rate as shown by a mean value of 3.21. However, this is close to the midpoint position, implying that the respondents were almost not sure as to whether the treasury bonds were decided upon because of their high rate of return in SACCOs in Baringo County. However, a significant standard deviation of 1.19 shows that there were varied responses as far as this was concerned. Similar findings have been reported by researchers such as Donald (2011) who found out that investing in treasuring bill is a reliable investment decision that SACCOs can embrace. The results further shows that the respondents agreed that there were guarantees of rerun on investment involving lending to the government as shown by a mean value of 3.34. However, this seems close to the midpoint implying that the respondents seemed to appreciate that the guarantee of rerun on investment involving lending to the government influenced financial performance of SACCOs. Nevertheless, a standard deviation of 0.93 suggested greater variation in the responses. This is in agreement with Donald (2011) who observes that lending to government demonstrated the SACCOs had faith in the returns fro lending to the government. In regard to whether lending to the government was based on considerations like research and market survey, the results suggest that the respondents agreed to a small extent with this indicator. This is revealed by a mean of 3.35. However a significant standard deviation of 1.06 suggests that there were varied responses as far as this test was concerned. The results further suggest that the respondents disagreed with the fact that their SACCO did not have capacity to lend to the government. This is revealed by a mean value of 2.51. However, a significant standard deviation of 1.09 suggests that respondents varied greatly in their responses to the statement.

\subsection{Financial performance of SACCOs}

This section presents the results on the financial performance of SACCOs in Baringo County. The financial 


\section{International Journal of Science and Research (IJSR) ISSN (Online): 2319-7064 \\ Index Copernicus Value (2013): 6.14 | Impact Factor (2015): 6.391}

performance was examined by analyzing the data under different dimensions of financial performance and computed for the mean and standard deviation as presented in Table 5 .

Table 5: Descriptive Statistics on Financial Performance of SACCOs

\begin{tabular}{|c|c|c|c|c|c|}
\hline Indicators/Statement & $N$ & Min & Max & Mean & SD \\
\hline $\begin{array}{c}\text { SACCOs' creditors repay loans } \\
\text { promptly }\end{array}$ & 142 & 1 & 5 & 3.97 & 0.23 \\
\hline $\begin{array}{c}\text { SACCOs determine customers' } \\
\text { creditworthiness }\end{array}$ & 142 & 1 & 5 & 2.71 & 0.92 \\
\hline $\begin{array}{c}\text { Credit reporting allows SACCOs to } \\
\text { distinguish between good and bad } \\
\text { borrowers }\end{array}$ & 142 & 1 & 5 & 4.24 & 1.06 \\
\hline $\begin{array}{c}\text { Our SACCO has enough cash to } \\
\text { meet its obligations effectively }\end{array}$ & 142 & 1 & 5 & 3.00 & 0.44 \\
\hline $\begin{array}{c}\text { Our SACCO's accounting system } \\
\text { adequately identifies the receipts and } \\
\text { expenditures }\end{array}$ & 142 & 1 & 5 & 2.21 & 1.05 \\
\hline $\begin{array}{c}\text { All fees, interests and members } \\
\text { contributions are dully collected }\end{array}$ & 142 & 1 & 5 & 3.14 & 0.89 \\
\hline $\begin{array}{c}\text { Outstanding fees are dully paid in } \\
\text { time }\end{array}$ & 142 & 1 & 5 & 3.11 & 0.07 \\
\hline $\begin{array}{c}\text { SACCO's asset base has increased } \\
\text { over time }\end{array}$ & 142 & 1 & 5 & 3.27 & 0.15 \\
\hline
\end{tabular}

Source: Author (2016)

From Table 5, the respondents believed that SACCOs' creditors repaid loans promptly as revealed by a mean value of 3.97 with a standard deviation of 0.23 . It is also evident that the respondents slightly agreed that their SACCOs determine customers' creditworthiness before undertaking any financial transaction with them as shown by a mean value of 2.71 although the standard deviation of 0.06 under the same test revealed no variation in responses. The findings in regard to whether credit reporting allowed the SACCOs to distinguish between good and bad borrowers shows that majority of the respondents were in agreement as revealed by a mean value of 4.24 with a standard deviation of 0.04 which revealed homogeneity of responses in regard to this test. It is also evident that the respondents were indifferent as to whether their SACCO had enough cash to meet its obligations effectively. This is revealed by a mean value of 3.00. However, a standard deviation of 0.95 reveals that the respondents varied in their responses. It is also evident that the respondents were indifferent as to whether their SACCO's accounting system adequately identified the receipts and expenditures as revealed by a mean value of 2.21. However, the standard deviation of 1.05 reveals that the respondents varied in their responses to this indicator of financial accountability. These findings appears to support the observation by Kargi (2011) that sometimes resources are mismanaged and misappropriated by those put in charge to ensure proper and efficient management of the resources to the detriment of the activity for which the resources have been made available.

From the findings presented, the respondents agreed that all fees, interests and members' contributions were dully collected as revealed by a mean value of 3.14. However, a significant standard deviation of 0.89 under the same test revealed varied responses. It is also evident that the outstanding fees were dully paid in time as shown by a mean value of 3.11 although the standard deviation of 0.07 under the same test revealed that there was no variation in the responses. In regard to whether the asset base of the SACCOs had greatly increased over time, the respondents slightly agreed as revealed by a mean value of 3.27 with a standard deviation of 0.15 which revealed no variation in the responses.

\subsection{Inferential Statistical Analysis}

The following section presents the inferential statistical analysis on data obtained from the study. The linear regression analysis for all the variables was done and the results obtained presented in table 6 .

Table 6: Linear Regressions for all the independent Variables

\begin{tabular}{|l|c|c|c|c|c|}
\hline \multicolumn{7}{|c|}{ Model 1 } & \multicolumn{5}{c|}{ Coefficients $^{\mathrm{a}}$} & \multirow{2}{*}{ Sig. } \\
\cline { 2 - 5 } & Unstandardized Coefficients & Standardized Coefficients & & \\
\hline Investment in Real Estate & .098 & .113 & .177 & 1.785 & .006 \\
\hline Lending to Members & .153 & .090 & .194 & 1.098 & .038 \\
\hline FOSA Activities & .166 & .066 & .155 & 1.822 & .011 \\
\hline Lending to Government & .107 & .080 & .174 & 1.098 & .008 \\
\hline
\end{tabular}

In summary in the order of relative effect of independent variable on dependent variable, the model is expressed as: SACCOs' Financial Performance $=0.396+0.166$ (FOSA Activities) + 0.153 (Lending to Members) + 0.098 (Investment in Real Estate) +0.107 (Lending to Government) + error.

\section{Conclusions and Recommendations}

\subsection{Conclusions}

The study concludes that investment in real estate predicted the financial performance of SACCOs in Baringo County. With an F statistic of 2.089 supported by a probability value of 0.049 , investment in real estate influenced $9.8 \%$ of the financial performance of SACCOs in Baringo County. It is also concluded that lending to members influenced the financial performance of SACCOs as indicated by the regression model in which lending to members predicted the outcome variable with an F statistic of 1.686 supported by a probability value of 0.011 . Hence, $15.3 \%$ of registered SACCOs' financial performance was explained by lending to members. The study also concludes that FOSA activities influenced the financial performance of SACCOs in Baringo County. The regression model on FOSA activities predicted the financial performance of SACCOs with an F statistic of 1.358 supported by a probability value of 0.01 . The study established that $16.6 \%$ of registered SACCOs' financial performance in Baringo County was explained by FOSA activities. Finally, the study concludes that lending to the government influenced the financial performance of SACCOs as indicated by the regression model in which 


\section{International Journal of Science and Research (IJSR) \\ ISSN (Online): 2319-7064 \\ Index Copernicus Value (2013): 6.14 | Impact Factor (2015): 6.391}

lending to the government predicted the outcome variable with an F statistic of 1.686 supported by a probability value of 0.011 . Based on this statistical analysis, $10.7 \%$ of registered SACCOs' financial performance in Baringo County was explained by lending to the government. In general, the study concludes that investment in real estate, lending to members, lending to Government and FOSA activities had a positive influence on the financial performance of SACCOs in Baringo County. The highest influence was explained by FOSA activities, followed by lending to members, then lending to the government and finally investment in real estate.

\subsection{Recommendations}

Based on the findings and conclusions drawn from the study, several recommendations are made. The study recommends that SACCOs in Baringo County need to expand their investment decisions in order to improve on their financial management. The study also recommends enhanced investment in real estate so as to improve financial ability of SACCOs in Baringo County. Through investment in real estate, the SACCOs will be able to diversify their investment portfolios. There is also need for SACCOs to embrace FOSA activities as this may help maximize and improve the financial status of registered SACCOs in Baringo County.

\section{References}

[1] Adeyemo, R. \& Bamire, A. S. (2005). Saving and investment Patterns of Co-operative farmers in Southwestern Nigeria. Journal of Social Science, 11(3): 183-192.

[2] Anyanwu, R. (2005). On capital structure, risk sharing and capital adequacy in Islamic Banks. International Journal of Theoretical and Applied Finance, 09(03), 269-280.

[3] Armstrong, M. (2006).Human Resource Practice and System Thinking. London: Kegan Page Publishers.

[4] Besley T \& S. Coate, E. (2005). Making Corporate Governance Count: The Fusion of Ethics and Economic Rationality. Journal of Management and Governance, 2(2), 135-147.

[5] Chambo, A., Mwangi, M. \& Oloo, O. (2013). An Analysis of the Socio-Economic Impact of Cooperatives and their Institutional Context in Kenya, International Cooperative Alliance and the Canadian Cooperative Association.

[6] Cole, G. A. (2004). Management theory and practice ( $6^{\text {th }}$ edition) Book power publishers, London.

[7] Dlamini, A. (2011). The impact of Savings and Credit Co-operatives on the Socio-economic development of Swaziland, Swaziland Government, Lobamba.

[8] Donald, B. (2010). The Stakeholder Theory of the Corporation: Concepts, Evidence and Implications. Academy of Management Review, 20, 65-91.

[9] Elhiraika, F. (2011). Management Research. 3rd edition, London: SAGE Publications Ltd.

[10] Evans A. C. (2001). Strengthening Credit Unions in Sri Lanka: Research Monograph, World Council Of Credit Unions, Madison: WI, USA.
[11] Freeman, K. (2008). A Theory of Capital Structure Adjustment Speed. Working paper, University of Florida, USA

[12] Gaitho, T. (2013). Factors that influence the growth of enterprises. A case study of enterprises participating in Msingi loan from Bomas in Thika District, JKUAT, MA Thesis, JKUAT, Juja, Kenya

[13] Kargi, B. (2011). Strategic Planning in Co-operative Sector: A Study on Dairy Co-operative. The Journal of Nepalese Business Studies, II (1), 72-80.

[14]Kithinji, A. (2010). Management of loan default problems in SACCOs in Nairobi province. MBA Thesis, JKUAT, Juja, Kenya.

[15] Lavio, M. (2002). Cadrisme within a Kaleckian Model of Growth and Distribution. Conf. University of Ottawa, Ottawa, Canada.

[16] Mantrala, K., Naik, A. \& Thorson, E. (2007). Uphill or Downhill? Locating the Firm on a Profit Function, Journal of Marketing, American Marketing Association, Columbia.

[17] Mbaabu, A. M. (2004). Determinants of Loan nonPerformers in Commercial Banks in Eldoret. MBA Thesis, Moi University, Eldoret, Kenya.

[18] Mbui, J. K. (2010). Business opportunities for Stima Sacco Society Limited in a new regulatory environment, Unpublished MBA Project, University of Nairobi.

[19] Munyiri, C. (2006). Study visit on the role of women in development of microfinance in Africa. Digest 03(3), 16.

[20] Muriuki, E. (2016). Determinants of Priority Structure of Corporate Liabilities For Firms Quoted At The NSE. Unpublished MBA Project, University Of Nairobi.

[21]Muriuki, M. (2010). Factors affecting Sacco performance in Meru South district: a case of Tharaka Nithi Teachers Sacco, Unpublished MBA project, University of Nairobi.

[22] Muruana, M. N. (2007). Effects of inflation on share capital and loan portfolio with the coop Organizations in Kenya. A case study of Chai saving and credit cooperative society. MBA thesis, Moi University, Eldoret, Kenya.

[23] Mwaura D. N. (2016). Factors affecting the performance of Savings and Credit Cooperative Societies in Kenya. A case study of Afya Cooperative Society Ltd. Nairobi, Kenya.

[24] Ndubi, T. M. (2006). Strategic Responses of SACCOs to changing operating Environment: a study of Nairobi Province KUSCO Affiliated SACCO. Nairobi, Kenya.

[25] Ngaira, L. (2011). The impact of SACCO Societies Regulatory Authority guidelines on SACCOs operations in Kenya-The case of Nairobi Deposit Taking SACCOS, Unpublished MBA Thesis, University of Nairobi.

[26] Ngui, A. N. (2010). A survey of the Use of Financial Performance Indicators by SACCOs in Kenya, An Unpublished MBA Thesis, University of Nairobi.

[27] Ochoki, A. N. (2007). Factors influencing failure of front offices of FOSA in SACCO societies in Kenya. MBA Thesis, Moi University, Eldoret, Kenya.

[28] Olando, C. O., Mbewa, M. O. \& Jagongo, A. (2012). Financial Practice as a Determinant of Growth of Savings and Credit Co-Operative Societies' Wealth 


\section{International Journal of Science and Research (IJSR) \\ ISSN (Online): 2319-7064}

Index Copernicus Value (2013): 6.14 | Impact Factor (2015): 6.391

Kenya, International Journal of Business and Social Science Vol. 3 No. 24.

[29] Ombado, G. (2010). Identifying and maximizing SACCO's potential. ACCOSA Newsletter. 2(2), 2-6.

[30] Phikwe, S. (2004). Savings and Credit Co-operativesFulfilling a banking Need, Motswedi publications, Botswana.

[31] Prasanna, C. (2008). Investment Analysis and Portfolio Management, New Delhi; Hill Publishing.

[32] Sigei, K. (2013). The impact of credit reference bureau in SACCOs in Baringo County. Unpublished MBA Project. University of Nairobi.

[33] Wasike, J. (2012). Corporate Governance Practices and Performance at Elimu Sacco in Kenya, Unpublished MBA project, University of Nairobi. 